\title{
Chemical thinning affects yield and return flowering in 'Jubileu' peach
}

\author{
Marcos Antônio Giovanaz ${ }^{1 *}$, Priscila Alvariza Amaral ${ }^{1}$, Mateus da Silveira Pasa ${ }^{2}$, Ana Paula Fernandes de Lima ${ }^{1}$, \\ Diego Weber ${ }^{l}$, José Carlos Fachinello ${ }^{3}$
}

$10.1590 / 0034-737 X 201663030008$

\begin{abstract}
Peach hand thinning improves fruit quality; however, it requires a high demand of labor and increases production costs. The objective of this study was to evaluate the effect of growth regulators applied at post-flowering as an alternative to hand thinning of peaches. The experiment was conducted with peach cultivar Jubileu, in 2012. The treatments consisted of no thinning, hand thinning 45 days after full bloom (DAFB), ethephon (85 and $\left.120 \mathrm{mg} \mathrm{L}^{-1}\right)$, benzyladenine (BA) $\left(400 \mathrm{mg} \mathrm{L}^{-1}\right)$, and BA plus gibberellic acid $\left(\mathrm{GA}_{4+7}\right)\left(400 \mathrm{mg} \mathrm{L}^{-1}\right)$ applied $40 \mathrm{DAFB}$. BA-treated plants were not different from non-thinned plants, had excessive load, and smaller diameter fruit. Treatment with ethephon at $120 \mathrm{mg} \mathrm{L}^{-1}$ resulted in excessive thinning and decreased yield in comparison with other treatments. Plants treated with 85 $\mathrm{mg} \mathrm{L} \mathrm{L}^{-1}$ ethephon and $\mathrm{BA}+\mathrm{AG}_{4+7}\left(400 \mathrm{mg} \mathrm{L}^{-1}\right)$ had fruit abscission, crop load, production per plant and fruit diameter similar to hand-thinned plants. In 2013, an increased number of flower buds was observed in treatments with ethephon and also reduction of this trait in $\mathrm{BA}$ and $\mathrm{BA}+\mathrm{GA}_{4+7}$ applications. Ethephon at $85 \mathrm{mg} \mathrm{L}^{-1}$ can be an alternative of chemical thinning in 'Jubileu' peaches, without compromising the return of flower bud numbers in the next crop.
\end{abstract}

Keywords: Prunus persica L., benzyladenine, growth regulators, ethephon, Promalin ${ }^{\circledR}$.

\section{RESUMO}

\section{Raleio químico afeta a produtividade e o retorno da floração em pessegueiro 'Jubileu'}

O raleio manual de frutos é realizado com o objetivo de melhorar a qualidade dos frutos; no entanto, exige alta demanda de mão de obra e encarece os custos de produção. Objetivou-se, com este trabalho, avaliar o efeito de fitorreguladores aplicados na pós-floração, que se possam constituir em alternativa ao raleio manual em pessegueiros. O experimento foi conduzido em 2012, com pessegueiros do cultivar Jubileu, em tratamentos que consistiram em plantas sem raleio, com raleio manual aos 45 dias após a plena floração (DAPF), com ethephon, a 85 e a $120 \mathrm{mg} \mathrm{L}^{-1}$, com benziladenina (BA) a $400 \mathrm{mg} \mathrm{L}^{-1}$ e com BA + ácido giberélico ${ }_{4+7}\left(\mathrm{AG}_{4+7}\right)$, a $400 \mathrm{mg} \mathrm{L}^{-1}$ aplicados aos 40 DAPF. Plantas tratadas com BA não diferiram das plantas do tratamento sem raleio e apresentarm carga excessiva e frutos com menor diâmetro. O tratamento com ethephon a $120 \mathrm{mg} \mathrm{L}^{-1}$ ocasionou raleio excessivo e diminuiu a produtividade, em comparação com a dos demais tratamentos. Plantas tratadas com $85 \mathrm{mg} \mathrm{L}^{-1}$ de ethephon e com $400 \mathrm{mg} \mathrm{L}^{-1} \mathrm{de} \mathrm{BA}+\mathrm{AG}_{4+7}$ apresentaram abscisão de frutos, carga de colheita, produção por planta e diâmetro dos frutos semelhantes aos das plantas sob raleio manual. No ano de 2013, foi observado aumento do número de gemas floríferas nos tratamentos com ethephon e redução nas aplicações de $\mathrm{BA}$ e $\mathrm{BA}+\mathrm{AG}_{4+7}$. A aplicação de ethephon na dose de $85 \mathrm{mg} \mathrm{L}^{-1}$ pode ser uma alternativa de raleio químico de frutos, em pessegueiros 'Jubileu', sem comprometer o retorno do número de gemas floríferas na safra subsequente.

Palavras-chave: Prunus pérsica L., benziladenina, fitorreguladores, ethephon, Promalin ${ }^{\circledR}$.

\footnotetext{
Received on March $12^{\text {th }}, 2015$ and approved on January 18 2016.

${ }^{1}$ Universidade Federal de Pelotas, Faculdade de Agronomia Eliseu Maciel, Departamento de Fitotecnia, Pelotas, Rio Grande do Sul, Brazil. giovanazmarcos@gmail.com prialvariza@gmail.com; ear_ana@hotmail.com; dieweb@gmail.com

2 Estação Experimental de São Joaquim, São Joaquim, Santa Catarina, Brazil. mateuspasa@epagri.sc.gov.br

${ }^{3}$ Universidade Federal de Pelotas, Departamento de Fitotecnia, Faculdade de Agronomia Eliseu Maciel, Pelotas, Rio Grande do Sul, Brazil. jfachi@ufpel.tche.br

*Corresponding author: giovanazmarcos@gmail.com
} 


\section{INTRODUCTION}

The objective of flower or fruit thinning is to reduce fruit number per plant, promoting source-drain balance and reducing competition among fruits for energy, which results in larger fruits with improved flavor and aroma (JR Dennis, 2000; Byers et al., 2003). However, hand thinning is an expensive work and requires high labor demand, raising production costs (Costa \& Vizzotto, 2000).

Labor availability for thinning is uncertain, which prompts the development of research on the replacement of hand thinning by chemical thinning (Mcartney et al., 2012). Peach chemical thinning is considered promising (Greene \& Costa, 2013) and can be performed from the dormant season, reducing the number of buds (Stern \& Ben-Aire, 2009), and flower thinning using caustic substances (Yoon et al., 2011), as well as in the postflowering phase (Costa et al., 2006).

Among the growth regulators for post-flowering thinning, ethephon has shown thinning effect on peaches from flowering to pit hardening (Byers et al., 2003; Greene $\&$ Costa, 2013). However, the temperature during and after the application is the most important environment factor to be considered, affecting both absorption and degradation of ethylene to ethephon (Yuan, 2007).

Although chemical fruit thinning is an established practice in apples, the synthetic cytokinin benzyladenine and its mixture with gibberellin 4 and 7 has not been reported in peach fruit thinning. The use of growth regulators in peach has not shown good results to date, with some growth regulators showing poor thinning and others no thinning at all. Also, there are few products with hormonal action, which promote abscission of fruit, available to be recommended in post-flowering stage (Greene \& Costa, 2013).

Therefore, this study aimed to evaluate different growth regulators applied at post-flowering as an alternative to hand thinning in peaches.

\section{MATERIALAND METHODS}

The experiment was conducted in a commercial peach orchard, in the minicipality of Morro Redondo, RS, Brazil (31 39 '55,09' S and 52 34'51,30' 'W), in 2012. Ten-year old peach trees cultivar Jubileu grafted on Capdeboscq rootstock were used in the study. Experiments were conducted using vase system plants at planting density of 833 plants ha $^{-1}$, spaced $6 \mathrm{~m}$ between rows and $2 \mathrm{~m}$ between plants. Soil fertilization was carried out according to the soil analysis.

Treatments consisted of: 1) Non-thinned trees; 2) hand thinning 45 days after full bloom (DAFB); 3) $85 \mathrm{mg} \mathrm{L}^{-1}$ Ethephon; 4) $120 \mathrm{mg} \mathrm{L}^{-1}$ Ethephon; 5) ) $400 \mathrm{mg} \mathrm{L}^{-1}$ benzyladenine (BA; and 5) $400 \mathrm{mg} \mathrm{L}^{-1}$ of both BA + gibberellins (4 and 7) $\left(\mathrm{BA}+\mathrm{GA}_{4+7}\right)$. The experiment was arranged in a randomized block design with four replications of three plants per plot, evaluating the central plant in the plot.

The chemical treatment was carried out at 40 DAFB, when fruit had $2 \mathrm{~cm}$ in diameter, and seeds had average length of $14 \mathrm{~mm}$. The different doses were sprayed with a knapsack sprayer with average water volume of $1000 \mathrm{~L} \mathrm{ha}^{-}$ ${ }^{1}$. Ethephon was applied in the form of Ethrel $^{\circledR}$, with $24 \%$ of the active ingredient (a i); BA in the form of Maxcel ${ }^{\circledR}(2 \%$ a i), and BA $+\mathrm{GA}_{4+7}$ in the form of Promalin ${ }^{\circledR}$, with $1.88 \%$ a i of each compound (1: 1). All treatments with growth regulators received $0.1 \%$ of nonionic adhesive spreader Break-Thru ${ }^{\circledR}$.

The effect of plant growth regulator in the field was evaluated by assessing fruit abscission in the shoots, which was determined by counting the fruits on six shoots distributed on both sides of the plant, and then again 35 days after application, with the results expressed as percentage of abscission. Also, before harvest, fruits of the whole plant were counted, trunk diameter at $20 \mathrm{~cm}$ from the ground was measured, the trunk cross-sectional area (TSCA) was calculated, and crop load was determined and expressed as the number of fruits $\mathrm{cm}^{-2}$ TSCA.

To carry out the laboratory analyses and yield determination, 40 fruits were randomly picked per repetition. The average fruit weight $(\mathrm{g})$ and yield per plant $(\mathrm{kg}$ per plant) were calculated. According to the diameters, the fruits were divided into four classes, $<47 \mathrm{~mm}, 47<57 \mathrm{~mm}$, $57<65 \mathrm{~mm}$ and $\geq 65 \mathrm{~mm}$. Soluble solids content (SS) was determined by digital refractometer and expressed in ${ }^{\circ}$ Brix. Titratable acidity (TA) was measured by neutralization with $0.1 \mathrm{~N} \mathrm{NaOH}$ to $\mathrm{pH} 8.1$ with $10 \mathrm{~mL}$ of sample in $90 \mathrm{~mL}$ of distilled water.

After harvest, the return of flower buds was evaluated during the dormant period in the following year. Flower buds were counted in six shoots of each plant, the shoot lengths were measured, and return was expressed as flower buds $\mathrm{cm}^{-1}$ shoot.

Data were examined by analysis of variance, and means were compared by the Duncan test. The statistical analysis was performed with the software SPSS Statistics 20.

\section{RESULTS}

Non-thinned trees had a natural abscission of 35\% fruit (Table 1). Ethephon at $85 \mathrm{mg} \mathrm{L}^{-1}$ caused abscission of $79 \%$ of the fruit, which was similar to the control (hand thinning) with $77 \%$ of abscission. The highest ethephon dose (120 $\mathrm{mg} \mathrm{L}^{-1}$ ) resulted in high abscission, reaching $91.3 \%$ of the fruit. $\mathrm{BA}+\mathrm{GA}_{4+7}$ at $400 \mathrm{mg} \mathrm{L}^{-1}$ also resulted in abscission of $77 \%$ of the fruit.

The crop load and fruit number per plant had the same trend as percentage of abscission (Table 1). The treatment 
with the highest abscission (ethephon $120 \mathrm{mg} \mathrm{L}^{-1}$ ) resulted in the lowest number of fruit per plant and, therefore, reduced production per plant; however, the average fruit weight was higher than the other treatments. The treatments $85 \mathrm{mg} \mathrm{L}^{-1}$ Ethephon and $400 \mathrm{mg} \mathrm{L}^{-1} \mathrm{BA}+\mathrm{GA}_{4+7}$ statistically had the same number of fruits per plant, the same crop load, and the same production of the control with hand thinning. The effect of $400 \mathrm{mg} \mathrm{L}^{-1} \mathrm{BA}$ alone, despite of showing slight abscission, was higher than the non-thinned treatment and not statistically different from the other variables, showing at the end of the harvest fruit per plant, average weight and production similar to the non-thinned plants.

The ethephon doses 85 and $120 \mathrm{mg} \mathrm{L}^{-1}$ increased the return of flower buds in the next season in comparison with the hand thinning treatment (Table 1). The application of BA alone reduced the return of flower buds, which was the same of non-thinned plants. The treatment $400 \mathrm{mg} \mathrm{L}^{-1}$ $\mathrm{BA}+\mathrm{GA}_{4+7}$, despite having provided a chemical thinning similar to hand thinning and not having differed in productivity, compromised the return flowering, which was reduced to 0.44 buds per centimeter shoot, a lower and significant value compared with the control treatment hand thinning, which showed 0.75 flower buds per shoot centimeter.

The fruits were divided into classes (Table 2). The smallest class had a low percentage of very small fruits for non-thinned plants. However, for the second, third and fourth classes, the same treatments whose results were similar to those of hand thinning in other variables, e.g. 85 $\mathrm{mg} \mathrm{L}{ }^{-1}$ ethephon and $400 \mathrm{mg} \mathrm{L}^{-1} \mathrm{BA}+\mathrm{GA}_{4+7}$, showed the same percentage of fruit classified into $47<57,57<65$ and $\geq 65 \mathrm{~mm}$. Again, only the treatment $120 \mathrm{mg} \mathrm{L}^{-1}$ ethephon, which had showed the highest weight mean among the treatments, showed a higher percentage of fruits classified as large ( $\geq 65 \mathrm{~mm})$. Table 2 shows that the treatments did not influence fruit chemical quality, with no statistical difference for the soluble solids and titratable acidity variables.

\section{DISCUSSION}

Since the 80's, extensive research has been developed with numerous chemicals aiming at chemical thinning in peaches; however, no product had satisfactory and consistent results in different years and climatic conditions (Costa \& Vizzotto, 2000).

Although controversial results are reported, ethephon has shown thinning effect on peaches (Byers et al., 2003; Greene \& Costa, 2013). Ethephon is absorbed by the plant tissue and hydrolyzed to release ethylene, which leads to inhibition of the synthesis or transport of auxin. Thus, ethephon application increases the tissue sensitivity to ethylene and abscission occurs as a consequence of increased synthesis and secretion of the enzyme cellulase (Dennis, 2000; Salaya, 2012).

According to Salaya (2012), better result on peach thinning is obtained depending on the length of the pit, and it is recommended to apply ethephon when seeds reach $12 \mathrm{~mm}$ in length, for cultivars intended for fresh consumption, and $14 \mathrm{~mm}$, for cultivars for industry. The few studies reported in the literature (Vego et al., 2010; Sardaki, 2012; Taheri et al., 2012; Meitei et al., 2013) on ethephon application to peach trees do not provide information on the time of application and the size of the fruit and seed, which makes it difficult to compare results, since the susceptibility of the plant to the product increases with fruit size (Salaya, 2012).

The application of ethephon to 'Redhaven' peach trees, in Canada, during hardening of the pit, may be considered commercially acceptable (Taheri et al., 2012). In South Australia, ethephon applied from 39 to 53 DAFB, at the concentrations of 40-100 $\mathrm{mg} \mathrm{L}^{-1}$, provided good results in 'Golden Queen', 'Wight' and 'Keimos' peaches (Gathercole, 1981). In Romania, Sardaki et al. (2012) recommend the use of 200 to $300 \mathrm{mg} \mathrm{L}^{-1}$ ethephon. In this study, $80 \mathrm{mg} \mathrm{L}^{-1}$ ethephon did not affect the production and provided fruits with commercial quality similar to hand thinned peaches. However, the small increase in

Table 1: Effects of chemical thinning and hand thinning on the percentage of abscission, plant load, production, production efficiency, average fruit weight and the return flowering in the harvest year 2013

\begin{tabular}{|c|c|c|c|c|c|c|c|}
\hline Treatments & $\begin{array}{c}\text { Time of } \\
\text { application }\end{array}$ & $\begin{array}{c}\% \\
\text { abscission }\end{array}$ & $\begin{array}{c}\text { Fruit } \\
\text { per plant }\end{array}$ & $\begin{array}{c}\text { Crop load } \\
\text { (fruit } \mathbf{c m}^{-2} \\
\text { TCSA) }\end{array}$ & $\begin{array}{c}\text { Average } \\
\text { weight (g) }\end{array}$ & $\begin{array}{c}\text { Production } \\
\text { (kg per plant) }\end{array}$ & $\begin{array}{c}\text { Flower bud } \\
\text { cm }^{-1} \text { shoot } \\
(2013)\end{array}$ \\
\hline No thinning & - & $35 \mathrm{~d}^{*}$ & $400 \mathrm{a}$ & $3.75 \mathrm{a}$ & $94 \mathrm{c}$ & $37 \mathrm{a}$ & $0.63 \mathrm{c}$ \\
\hline Hand thinning & 45 DAFB & $79 \mathrm{~b}$ & $237 \mathrm{c}$ & $2.25 \mathrm{c}$ & $116 \mathrm{~b}$ & $27 \mathrm{~b}$ & $0.75 \mathrm{~b}$ \\
\hline Ethephon $85 \mathrm{mg} \mathrm{L}^{-1}$ & 40 DAFB & $77 \mathrm{~b}$ & $269 c$ & $2.26 \mathrm{c}$ & $116 \mathrm{~b}$ & $31 \mathrm{ab}$ & $0.90 \mathrm{a}$ \\
\hline Ethephon $120 \mathrm{mg} \mathrm{L}^{-1}$ & 40 DAFB & $91 \mathrm{a}$ & $141 \mathrm{~d}$ & $1.07 \mathrm{~d}$ & $138 \mathrm{a}$ & $20 \mathrm{c}$ & $0.88 \mathrm{a}$ \\
\hline BA $400 \mathrm{mg} \mathrm{L}^{-1}$ & 40 DAFB & $51 \mathrm{c}$ & $343 \mathrm{c}$ & $3.01 \mathrm{~b}$ & $108 \mathrm{bc}$ & $37 \mathrm{a}$ & $0.57 \mathrm{c}$ \\
\hline $\mathrm{BA}+\mathrm{AG}_{4+7} 400 \mathrm{mg} \mathrm{L}^{-1}$ & 40 DAFB & $77 \mathrm{~b}$ & $270 \mathrm{bc}$ & $1.96 \mathrm{c}$ & $116 \mathrm{~b}$ & $31 \mathrm{~b}$ & $0.44 \mathrm{~d}$ \\
\hline
\end{tabular}

"Means followed by different small letters in the columns are significantly different by the Duncan test at $5 \%$ probability level. 
Table 2: Effects of chemical thinning and hand thinning on fruit chemical quality and fruit diameter, divided in classes

\begin{tabular}{|c|c|c|c|c|c|c|c|}
\hline Treatments & $\begin{array}{c}\text { Time of } \\
\text { application }\end{array}$ & $\begin{array}{c}<4 \mathrm{~mm} \\
(\%)\end{array}$ & $\begin{array}{c}47<57 \mathrm{~mm} \\
(\%)\end{array}$ & $\begin{array}{c}57<65 \mathrm{~mm} \\
(\%)\end{array}$ & $\begin{array}{c}\geq 65 \mathrm{~mm} \\
(\%)\end{array}$ & $\begin{array}{c}\text { S S } \\
\left({ }^{\circ} \text { Brix }\right)\end{array}$ & $\begin{array}{c}\mathrm{AT} \\
\left(\operatorname{meq} 100 \mathrm{~mL}^{-1}\right)\end{array}$ \\
\hline No thinning & - & $4.5 \mathrm{a}^{1}$ & $63.7 \mathrm{a}$ & $31.7 \mathrm{c}$ & $0 \mathrm{c}$ & $11.4^{\mathrm{ns}}$ & $11.5^{\mathrm{ns}}$ \\
\hline Hand thinning & 45 DAFB & $0 \mathrm{~b}$ & $18.0 \mathrm{c}$ & $75.2 \mathrm{a}$ & $6.7 \mathrm{bc}$ & 12 & 12.1 \\
\hline Ethephon $85 \mathrm{mg} \mathrm{L}^{-1}$ & 40 DAFB & $0 \mathrm{~b}$ & $28.7 \mathrm{bc}$ & $63.5 \mathrm{ab}$ & $7.7 \mathrm{bc}$ & 12.1 & 12.1 \\
\hline Ethephon $120 \mathrm{mg} \mathrm{L}^{-1}$ & 40 DAFB & $0 \mathrm{~b}$ & $9.0 \mathrm{c}$ & $65.0 \mathrm{ab}$ & $26.2 \mathrm{a}$ & 12.1 & 12.3 \\
\hline BA $400 \mathrm{mg} \mathrm{L}^{-1}$ & 40 DAFB & $0 \mathrm{~b}$ & $43 \mathrm{~b}$ & $54.7 \mathrm{~b}$ & $2.7 \mathrm{bc}$ & 11.1 & 11.8 \\
\hline $\mathrm{BA}+\mathrm{AG}_{4+7} 400 \mathrm{mg} \mathrm{L}^{-1}$ & 40 DAFB & $0 \mathrm{~b}$ & $26.7 \mathrm{bc}$ & $63.7 \mathrm{ab}$ & $9.5 \mathrm{~b}$ & 12.4 & 11.6 \\
\hline
\end{tabular}

${ }^{*}$ Means followed by different small letters in the columns are significantly different by the Duncan test at $5 \%$ probability level. ${ }^{\text {ns }}$ non significant.

concentration to $120 \mathrm{mg} \mathrm{L}^{-1}$ led to production loss. The doses suggested in the literature are different and ususally higher than that used in this experiment

BA application is commercially used in chemical fruit thinning of apples. When performed at the right time, observing the carbohydrate accumulation method, developed by Lakso et al., (1999), the product works well. The application of BA for chemical thinning of peach is not reported in the literature, and even the high dose of $400 \mathrm{mg} \mathrm{L}^{-1} \mathrm{BA}$ used in this work, compared with the doses used on apple trees (100 to $150 \mathrm{mg} \mathrm{L}^{-1}$ ), was not enough to cause good fruit abscission, resulting in overloaded trees (Greene et al., 2011).

The high concentration $\left(400 \mathrm{mg} \mathrm{L}^{-1}\right)$ of $\mathrm{BA}+\mathrm{GA}_{4+7}$ provided good fruit thinning; however, it reduced the number of flower buds, which can compromise production of the following year. Gibberellins are used as indirect thinning in peaches, and its application in floral induction period can reduce the return flowering (Stern \& Ben-Aire, 2009). Besides thinning, ethephon increased the number of flower buds in the next crop. This growth regulator is used in pears and apples to increase the number of flowers in the next season (McArtney et al., 2007, Einhorn et al., 2014).

The reduction in plant load reduces initial competition for carbohydrates, thereby improving the distribution of assimilates between fruit, producing fruit with greater mass and diameter (Byers et al., 2003). In this study, similar results were found with ethephon $120 \mathrm{mg} \mathrm{L}^{-1}$. However, when the plant load is excessive, the initial competition, during the period of fruit cell division, is high and the leaf area is not sufficient to support the number of fruit on the plant, reducing fruit mass and diameter.

Chemical thinning performance depends on the effectiveness of chemical diluents and variables such as time of application, product concentration, environmental conditions and the specific characteristics of each cultivar (Taylor \& Geisler-Taylor, 1998). Moreover, any modification of these variables can lead to undesirable results. Therefore, despite the plant regulator ethephon having potential for thinning, with performance similar to hand thinning, it still needs adjustments for its safe utilization in chemical thinning of peach.

\section{CONCLUSIONS}

The application of ethephon 40 DAFB at a concentration of $85 \mathrm{mg} \mathrm{L}^{-1}$ promotes fruit abscission in 'Jubileu' peach, without compromising production.

The application of ethephon at 40 DAFB increases the return of flower buds in the next crop, whereas the use of $\mathrm{BA}+\mathrm{GA}_{4+7}$ reduces the next crop number of flower buds.

\section{REFERENCES}

Byers RE, Costa G \& Vizzotto G (2003) Flower and fruit thinning of Peach and other Prunus. Horticultural Reviews, 28:351392.

Costa G \& Vizzotto G (2000) Fruit thinning of peach trees. Plant growth regulation, 31:113-119.

Costa G, Dalcin V \& Ramina A (2006) Physiological, Molecular and Practical Aspects of Fruit Abscission. Acta Horticulturae, 727:301-310.

Dennis FG JR (2000) The history of fruit thinning. Plant Growth Regulation, 31:01-16.

Einhorn TC, Pasa MS \& Turner J (2014) 'D'Anjou' pear shoot growth and return bloom, but not fruit size, are reduced by prohexadione-calcium. HortSience, 49:180-187.

Gathercole FJ (1981) Thinning of cling peaches with ethephon in Riverland area of South Australia. Australian of Experimental Agriculture and Animal Husbandry, 21:354-356.

Greene DW, Schupp JR \& Winzeler HE (2011) Effect of abscisic acid and benzyladenine on fruit set and fruit quality of apples. HortScience, 46:604-609.

Greene DW \& Costa G (2013) Fruit Thinning in Pome- and StoneFruit: State of the Art. Acta Horticulturae, 998:93-102.

Lakso AN, Wünsche JN, Palmer JW \& Corelli-Grappadelli L (1999) Measurement and modeling of carbon balance of the apple tree. HortScience, 34:1040-1047.

MCartney SJ, Unrath D, Obermiller D \& Green A (2007) Naphthaleneacetic Acid, Ethephon, and Gibberellin A4 + A7 Have Variable Effects on Flesh Firmness and Return Bloom of Apple. HortTechnlogy, 17:32-38. 
MCartney SJ, Obermiller JD \& Arellano C (2012) Comparison of the effects of metamitron on chlorophyll fluorescence and fruit set in apple and peach. HortScience, 47:509-514.

Meitei SB, Patel RK, Deka BC, Deshmukh NA \& Singh A (2013) Effect of chemical thinning on yield and quality of peach $\mathrm{cv}$. Flordasun. African Journal of Agricultural Research, 8:33583565 .

Salaya GFG (2012) Fruticultura - La producción de fruta: Frutas de clima templado y subtropical. $3^{\text {a }}$ ed. Chile, Universidade do Chile. 643p.

Sardaki BL (2012) Study upon the impact of chemical thinning with ethephon on the quality of tow peach varieties cultivated in the western part of Romania. International Research Journal of Agricultural Science and Soil Science, 2:413-420.

Stern RA \& Ben-Arie R (2009) GA3 Inhibitis flowering, reduces hand-thinning, and increases fruit size in peach and nectarine. Journal of Horticultural Science \& Biotechnology, 84:119-124.
Taheri A, Cline JA, Jayasankar S \& Pauls PK (2012) Ethephoninduced abscission of "Redhaven" peach. American Journal of Plant Sciences, 3:295-301.

Taylor BH \& Geisler-Taylor D (1998) Flower bud thinning and winter survival of "Redhaven" and "Cresthaven" peach in response to $\mathrm{GA}_{3}$ sprays. American Journal of Horticulturae Science, 123:500-508.

Vego D, Saravanja P \& Knezovic Z (2010) Fruit thinning of peach and nectarine. Acta Horticulturae, 884:695-700.

Yoon TM, Osborne J \& Robinson TL (2011) Blossom thinning of 'Redhaven' and 'Babygold 5' peaches with different chemicals. Acta Horticulturae, 903:833-840.

Yuan R (2007) Effects of temperature on fruit thinning with ethephon in 'Golden Delicious' apples. Scientia Horticulturae, 113:08-12. 